\title{
Thalassaemia types and their incidence in Sardinia
}

\author{
A. CAO, R. GALANEllo, M. FURBETtA, P. P. MURONi, L. GARBATO, \\ C. ROSATELLI, M. T. SCALAS, M. ADDIS, R. RUGGERI, L. MACCIONI, \\ AND M. A. MELIS
}

From the 2nd Pediatric Clinic, University of Cagliari, Sardinia, Italy

SUMMARY The frequency of thalassaemia syndromes in Sardinia was examined by a population survey. The data indicate that about $12.6 \%$ of the Sardinian subjects are carriers of $\beta$-thalassaemia, while $6.9 \%$ of the population carries an $\alpha$-thalassaemia gene, with a slight difference between the various provinces. These are among the highest frequencies of thalassaemia genes found in a Caucasian population today.

A survey of hospital inpatients and outpatients showed a newborn incidence of homozygous $\beta$ thalassaemia of 1 in 300. The reasons for the difference between the expected and observed incidence figures are discussed. Moreover, 3 subjects with $\delta \beta^{0}$-thalassaemia trait, 6 carriers of heterocellular persistence of fetal haemoglobin (HPFH), 1 sickle cell trait, and 3 subjects with Hb J Sardegna were found.

Genetic heterogeneity of $\beta$-thalassaemia syndromes in this population may generally result from the interaction of $\alpha$ - and $\beta$-thalassaemia genes.

The incidence and distribution of thalassaemia syndromes in Sardinia have been previously investigated (Silvestroni and Bianco, 1960; Carcassi, 1963; Siniscalco et al., 1966). However, the osmotic fragility test and the examination of blood smears have usually been the only tests used in these population surveys. Therefore, there is no clear data on the extent of heterogeneity of thalassaemia syndromes in this island.

Recently, in a group of 233 people from the Cagliari province, randomly selected on the basis of $\mathrm{Hb} \mathrm{A}_{1} / \mathrm{Hb}$ $A_{2}$ ratio, Terrenato (1973) observed 2 groups of thalassaemia carriers: $\beta$-thalassaemia carriers with high $\mathrm{Hb} \mathrm{A}_{2}$ with a phenotypic percentage of $9.4 \%$, and non- $\beta$-thalassaemia carriers with normal $\mathrm{Hb} \mathrm{A_{2 }}$ and $\mathrm{Hb} \mathrm{F}$, with a frequency of $8 \cdot 2$. According to the author, the members of this last group were probably $\alpha$-thalassaemia carriers.

The present study was undertaken in order to obtain information on the frequency and distribution of thalassaemia carriers in Sardinia.

\section{Materials and methods}

\section{SUBJECTS STUDIED}

Voluntary testing for thalassaemia was offered to various population groups. All the subjects examined, aged 14 to 45 years, were of Sardinian extraction. A comprehensive programme was sponsored by the Trade Unions. The programme included community education, considerable publicity, confidentiality of the results, and individual counselling for people found to be carriers. Follow-up sessions were provided for families of people who were found to be carriers.

The results of the parents and other relatives of people with $\beta$-thalassaemia major were excluded from the calculation of the thalassaemia frequency.

\section{HAEMATOLOGICAL AND HAEMOGLOBIN}

ANALYTICAL STUDIES

Blood samples were collected and stored in heparin. Haematological data were obtained using the Coulter Counter ZBI and Coulter Hemoglobinometer. Haemoglobin electrophoresis was carried out on cellulose acetate plates (Helena Laboratories, Beau-

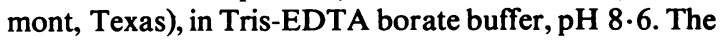


$\mathrm{Hb} \quad \mathrm{A}_{2}$ was quantified by DE-52 microchromatography (Huisman et al., 1975). The one-tube osmotic fragility test using $0.4 \%$ buffered $\mathrm{NaCl}$ was performed using the method of Silvestroni and Bianco (1945). Hb F was measured by alkali denaturation (Betke et al., 1959), and serum iron and iron binding capacity by the method of Lauber (1965). Hb H inclusion bodies were obtained by mixing equal volumes of whole blood and $1 \%$ brilliant cresyl blue in citrate saline solution and incubating at $37^{\circ} \mathrm{C}$ for 20 minutes to 1 hour.

To estimate the incidence of Cooley's anaemia, we examined all hospital records and outpatient registers of the paediatric departments which take care of thalassaemia patients in the Cagliari and Oristano provinces. The frequency at birth of Cooley's anaemia per year was calculated using the yearly number of births in the same provinces. This calculation was limited to the last 2 years because up to that time many patients were referred to hospitals outside the island.

\section{DIAGNOSTIC SCHEME AND CRITERIA OF DIAGNOS IS}

All subjects had the following examinations: red blood cell count, haemoglobin quantification, packed red cell volume, $\mathrm{MCV}, \mathrm{MCH}, \mathrm{MCHC}$, one-tube osmotic fragility test, haemoglobin electrophoresis, and quantification of $\mathrm{Hb} \mathrm{A}_{2}$.

The diagnosis of $\beta$-thalassaemia carrier was made on the basis of reduced MCV, and reduced osmotic fragility, associated with high $\mathrm{Hb} \mathrm{A}_{2}$ levels (Fig.). Estimation of $\mathrm{Hb} \mathrm{A}_{2}$ levels with DE-52 microchromatography in our laboratory in samples from normal subjects gave values of between 1.71 to
3.20 (mean $2.50 \pm 0.43$ ), and in $\beta$-thalassaemi\& heterozygous values of between 4.23 to 6.80 (meand $5.35 \pm 0.55$ ) (Galanello et al., 1977). $\mathrm{Hb} \mathrm{A_{2 }}$ levelo were determined in all subjects, since in our experi ence and in accordance with the data of other authors $\overrightarrow{\bar{s}}$ (Pootrakul et al., 1973; Pearson et al., 1974; Mazza et al., 1976), the osmotic fragility test and MCV assess $\widetilde{-}$ ment may give false negative results. In fact, in the subjects with a diagnosis of $\beta$-thalassaemia trait, base on microcytosis and raised $\mathrm{Hb} \mathrm{A_{2 }}$ levels, the one-tubê osmotic fragility test gave false negative results irf $3.6 \%$ of the cases. On the other hand, in the mas $\overrightarrow{0}$ screening of our population this test gave false positive results in $6.5 \%$ of cases. These were probably carrier of $a$-thalassaemia.

In our laboratory, MCV gave a high number of false negative results too. Taking $79 \mathrm{fl}$ in males and $7 \mathrm{G}$ $\mathrm{fl}$ in females as minimum normal values (normal $\mathrm{b}$ SD), $3.0 \%$ of male and $3.8 \%$ of female $\beta$-thalas + saemia carriers had normal values (unpublishedu results).

All subjects with low MCV and normal or reduced $\mathrm{Hb} \mathrm{A}_{2}$ levels had iron studies performed. Subject showing $\mathrm{Hb} \mathrm{F}$ by electrophoresis had quantification of this haemoglobin.

As a preliminary to this survey, a series of experi甲 ments was carried out to ascertain the lowest level of $\mathrm{Hb} \mathrm{F}$ that can be distinguished by our method. Sefiat dilution of a haemolysate containing about $10 \%$ HPF was made with a normal adult haemolysate, cont ing $0.6 \% \mathrm{Hb} \mathrm{F}$, of the same concentration, and mixture was analysed by cellulose acetate electrō phoresis as described in the Methods section. It was found that $\mathrm{Hb} F$ was easily identified when its concen尺 tration was about $2 \%$ of total haemoglobin. Therefore $\vec{\rho}$

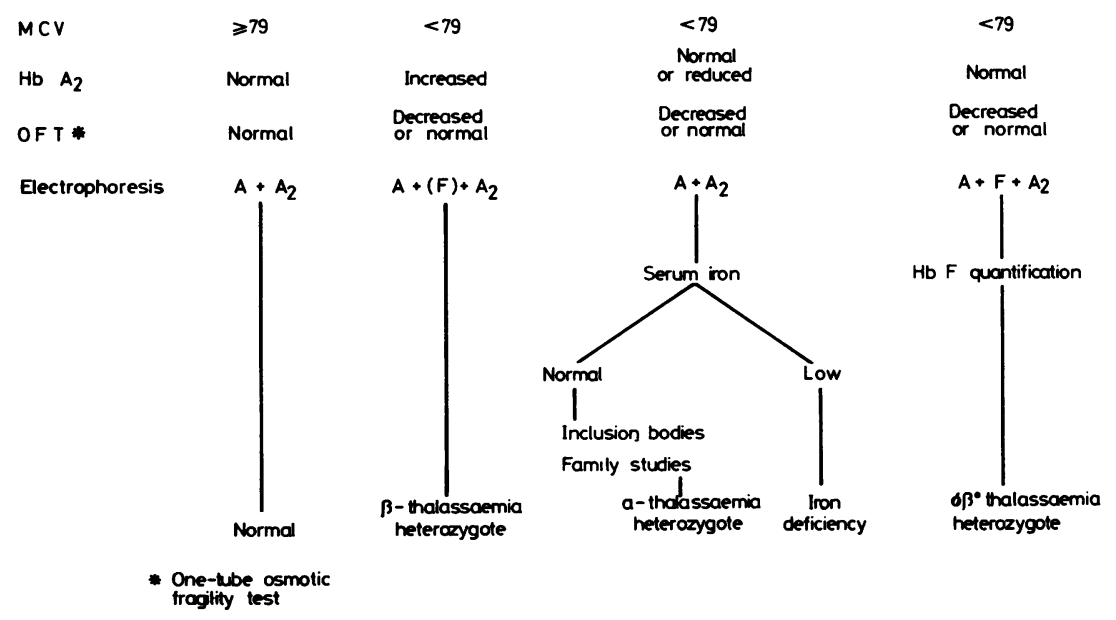

Fig. Scheme for mass screening for thalassaemia syndromes. 
it is probable that, with this method, we have missed some $\delta \beta^{+}$-thalassaemia heterozygotes or heterocellular HPFH carriers who had low levels of $\mathrm{Hb} F$.

Cases with microcytosis, low or normal $\mathrm{Hb} \mathrm{A_{2 }}$ levels, $\mathrm{Hb} F$ levels higher than $5 \%$, heterogeneously distributed, were considered to have the $\delta \beta^{0}$-thalassaemia trait.

Subjects with microcytosis, normal Hb F, normal or reduced $\mathrm{Hb} \mathrm{A}_{2}$, and normal serum iron were diagnosed as having the $a$-thalassaemia trait when the $\mathrm{Hb} \mathrm{H}$ inclusion bodies test was positive and/or a first degree relative showed the same haematological findings. The presence of rare cells with $\mathrm{Hb} \mathrm{H}$ inclusion bodies was observed in $78 \%$ of subjects with the above characteristics.

In a group of 20 randomly selected subjects showing these thalassaemia-like red cell indices, globin chain synthesis studies gave an $\alpha / \beta$ ratio of $0.66 \pm$ $0 \cdot 10$ (unpublished results). In these subjects identified as $\alpha$-thalassaemia carriers on the basis of $\alpha / \beta$ ratio, the percentage of positive $\mathrm{Hb} \mathrm{H}$ inclusion body tests was found to be similar.

Nevertheless, it is possible that some cases categorised as having $\alpha$-thalassaemia were in part carriers of $\beta$-thalassaemia with normal levels of haemoglobin $A_{2}$ and $F\left(\delta \beta^{+}\right.$-thalassaemia).

\section{Results}

\section{THALASSAEMIA CARRIER FREQUENCY AND DISTRIBUTION}

The results are summarised in the Table. In the Cagliari and Oristano provinces (Southern Sardinia), $12.9 \%$ of the 2400 people tested were found to have the $\beta$-thalassaemia trait and $6.6 \%$ the $\alpha$-thalassaemia trait.

Three subjects with the $\delta \beta^{0}$-thalassaemia trait, one with the sickle cell trait, and two carriers of $\mathrm{Hb} \mathrm{J}$ Sardegna were observed.

In addition, 6 people with normal haematological findings, normal osmotic fragility, and $\mathrm{Hb} \mathrm{\textrm {A } _ { 2 }}$ levels ranging from $2 \cdot 17$ to $2 \cdot 87 \%$ had $\mathrm{Hb} F$ levels ranging from $1 \cdot 5$ to $5 \cdot 2 \%$, heterogeneously distributed.
The Table also shows the distribution of the different traits in the other two provinces in the centre and north of the island (Nuoro and Sassari). In these provinces, the incidence figures for $\beta$-thalassaemia did not differ from those observed in Southern Sardinia. However, it is worth pointing out that there was a higher incidence of the $a$-thalassaemia trait in the Nuoro province, where the screening programme even revealed a patient with $\mathrm{Hb} \mathrm{H}$ disease.

\section{HOSPITAL SURVEY}

Patients with Cooley's anaemia, 51 born in 1975 and 53 born in 1976, were admitted or examined as outpatients in the paediatric haematological centres of the Cagliari province at least once.

In these 2 years the number of live births in the Cagliari and Oristano provinces was 16083 and 15163 , respectively. The newborn incidence of Cooley's anaemia in the Cagliari and Oristano provinces is, therefore, 1 in 300 .

\section{Discussion}

The $\beta$-thalassaemia carrier frequency found in our study gives a gene frequency of 0.065 , which is in accordance with the figure of 0.05 observed by Terrenato (1973).

This frequency is much lower than previous estimates (Silvestroni and Bianco, 1960; Carcassi, 1963; Siniscalco et al., 1966). With this frequency, the couples at risk are 1 in 60 and the expected incidence at birth of homozygous $\beta$-thalassaemia is 1 in 250 .

Even with this figure, Sardinia shows one of the highest frequencies of $\beta$-thalassaemia among Caucasian populations.

The difference between the expected and observed figures of the incidence of Cooley's anaemia in the Cagliari and Oristano provinces probably depends on 2 factors. Firstly, the sampling method was not strictly random, because people with a family history of anaemia may have been more likely to participate in the screening programme. This fact tends to introduce a bias which produces a rise in the true incidence.

Table Incidence of thalassaemia syndromes and hereditary haemoglobinopathies in Sardinia

\begin{tabular}{|c|c|c|c|c|c|c|c|c|c|}
\hline & \multicolumn{3}{|c|}{ Cagliari and Oristano provinces } & \multicolumn{3}{|c|}{ Nuoro province } & \multicolumn{3}{|c|}{ Sassari province } \\
\hline & $\begin{array}{l}\text { Subjects } \\
\text { examined }\end{array}$ & $\begin{array}{l}\text { Abnormal } \\
\text { subjects }\end{array}$ & $\%$ & $\begin{array}{l}\text { Subjects } \\
\text { examined }\end{array}$ & $\begin{array}{l}\text { Abnormal } \\
\text { subjects }\end{array}$ & $\%$ & $\begin{array}{l}\text { Subjects } \\
\text { examined }\end{array}$ & $\begin{array}{l}\text { Abnormal } \\
\text { subjects }\end{array}$ & $\%$ \\
\hline & 2400 & 482 & $20 \cdot 1$ & 459 & 94 & $20 \cdot 5$ & 294 & 54 & 18.4 \\
\hline$\beta$-thalassaemia heterozygotes & & 310 & $12 \cdot 9$ & & 54 & $11 \cdot 8$ & & 34 & $11 \cdot 6$ \\
\hline a-thalassaemia heterozygotes & & 160 & $6 \cdot 7$ & & 39 & $8 \cdot 5$ & & 19 & $6 \cdot 5$ \\
\hline$\delta \beta^{0}$-thalassaemia heterozygotes & & 3 & 0.12 & & & & & & \\
\hline Heterocellular HPFH heterozygotes & & 6 & 0.25 & & & & & & \\
\hline Hb J Sardegna carriers & & 2 & 0.08 & & & & & 1 & 0.3 \\
\hline Sickle-cell trait & & 1 & 0.04 & & & & & & \\
\hline Hb H disease & & & & & 1 & 0.2 & & & \\
\hline
\end{tabular}


Secondly, the direct calculation of the frequency of Cooley's anaemia, though reasonably accurate, is subject to considerable underestimation. In fact, some patients are unlikely to be ascertained by this kind of survey, because in our country some parents are against treatment of this disease in their children. Moreover, it is possible that in some patients, born in the last 2 years, the disease has not yet been clearly expressed at the phenotypic level. This fact would cause a reduction in the number of patients observed.

In this survey, 3 subjects with the $\delta \beta^{0}$-thalassaemia trait were found. The data showed that the thalassaemia mutation at $\beta$ locus or $\delta \beta$ loci is heterogeneous in Sardinia. In fact, 2 have been ascertained and there are probably more.

However, classic $\beta$-thalassaemia with high $\mathrm{Hb} \mathrm{A}_{2}$ is by far the most prevalent, as has been shown in this work.

In accordance with this, all the parents but 2 (who were $\delta \beta^{0}$-thalassaemia carriers) out of 350 Southern Sardinian patients affected by $\beta$-thalassaemia syndromes turned out to be classic $\beta$-thalassaemia carriers.

Further evidence of the prevalence of the $\beta$-thalassaemia trait with high $\mathrm{Hb} \mathrm{A}_{2}$ can be derived from the observation that 107 out of 350 patients, randomly selected for globin chain synthesis studies, were found to be homozygous $\beta^{0}$-thalassaemia carriers (unpublished results).

Since the present survey shows a high incidence of $a$-thalassaemia in our population, the heterogeneity of $\beta$-thalassaemia syndromes may depend on the concurrent inheritance of an $\alpha$-thalassaemia gene which can modify the degree of chain imbalance and reduce the clinical severity of the disease (Kan and Nathan, 1970; Bate and Humphries, 1977). Less frequently, the interaction between homozygous $\beta$-thalassaemia and heterocellular HPFH gene could result in the same effect, as suggested by Wood et al. (1977).

Because of the high number of false negative and false positive results, the one-tube osmotic fragility test and MCV assessment cannot be considered reliable for genetic screening for $\beta$-thalassaemia syndromes in our island. Thus, we think the diagnostic scheme proposed by us in the Methods section is necessary to avoid missing carriers.

In the present survey, a patient with $\mathrm{Hb} \mathrm{H}$ disease was observed and a high frequency of an $a$-thalassaemia trait was found. It must be taken into account that this incidence figure could be slightly lower, as it is possible with our approach to have diagnosed some $\beta$-thalassaemia carriers with normal levels of haemoglobin $\mathrm{A}_{2}$ and $\mathrm{F}$ as $a$-thalassaemia carriers. In the last 3 years, 24 patients with $\mathrm{Hb} \mathrm{H}$ disease were observed in our haematological service, which takes care of the population of Southern Sardinia. In general, on the basis of the haematological data and the $\alpha / \beta$ ratio, the genetics of $\mathrm{Hb} \mathrm{H}$ disease in Sardinia follow a pattern similar to that observed in Orientals: one paren showing thalassaemia-like red cell indices associated: with a low $\alpha / \beta$ ratio, and the other haematologically normal with a slight $\alpha / \beta$ chain imbalance (Galanelles et al., 1978). A newborn screening survey of $229 \mathrm{E}$ subjects for the presence of $\mathrm{Hb}$ Bart's in the sames population revealed a detectable amount, $>1 \%$ in about $12.6 \%$. The distribution of Hb Bart's appears tô be trimodal: $7.0 \%$ of the subjects had 1 to $2 \%$ of $\mathrm{Hb}^{\circ}$ Bart's, $5.6 \%$ had about 3 to $5 \%$ of Hb Bart's, and 4 subjects had about $25 \%$ of Hb Bart's. However, in the same population $\mathrm{Hb}$ Bart's hydrops fetalis syn drome has never been observed (unpublished results).

Further investigations, particularly family studies? and follow-up of newborn babies showing $\mathrm{Hb}$ Bart's higher than $1 \%$ at birth, and cDNA/DNA hybrides isation experiments, are needed to determine thes molecular pathology of $a$-thalassaemia in Sardinia.

The gene frequency of $a$-thalassaemia was not calcus lated because the problem of the number of $a$ loci has not yet been clarified, at least in Sardinia.

In this screening, a subject with sickle cell trait waß observed. One of his grandparents was of Turkish extraction. This confirms previous findings on the absence of the sickle cell trait in the Sardinianpopulation (Siniscalco et al., 1966).

It is well known that the frequency of the $\mathrm{Hb} \mathrm{S}$ gene is usually inversely correlated with that of $\beta$-thala asso saemia in the populations which show a high quency of these genes (Barnicot et al., 1963).

$\mathrm{Hb}$ J Sardegna (Tangheroni et al., 1968) ha\$ been described on numerous occasions in Sardiniß (Macciotta et al., 1969; Tangheroni et al., 1969). In thi survey, 3 subjects with this haemoglobin variant were 3 found, giving a carrier frequency of 1 in 1000 .

Four unrelated subjects with $\mathrm{Hb} \mathrm{F}$ levels ranging from 1.5 to $5 \cdot 2 \%$, with no haematological abnor malities, were observed. This could be a low estimate because our diagnostic scheme can miss some of these carriers.

Since $\mathrm{Hb} \mathrm{F}$ was heterogeneously distributed amongs the red blood cells, this condition may be a form oह heterocellular HPFH, as recently defined by BoyeP et al. (1977). It appears similar to the Swiss type (Marti, 1963; Knox-Macaulay et al., 1973), with Hb Fo heterogeneously distributed among the red cells in the 1 to $2 \%$ range.

The $\mathrm{Hb} \mathrm{F}$ levels in the 1.5 to $5.2 \%$ range is the main difference between the type of HPFH described here and that recently reported in a British family which showed higher $\mathrm{Hb} F$ levels segregating in groups with mean values of $19.8 \%$ in homozygous and $8.9 \%$ in heterozygous, subjects (Weatherall et al. 1975). 
Family studies, biosynthetic experiments, and $\mathrm{Hb} \mathrm{F}$ structural analysis, to characterise this haematological abnormality, are in progress.

We thank Rita Loi and Kate Testa for their excellent editorial assistance.

This work was supported by grants from the Assessorato Igiene e Sanità della Regione Autonoma della Sardegna, Sindacato Lavoratori Bancari, and CNR contract number 770062686 .

\section{References}

Barnicot, N. A., Allison, A. C., Blumberg, B. S., Deliyannis, G., Krimbas, C., and Ballas, A. (1963). Haemoglobin types in Greek populations. Annals of Human Genetics, 26, 229-236.

Bate, C. M., and Humphries, G. (1977). Alpha-beta thalassemia. Lancet, 1, 1031-1033.

Betke, K., Marti, H. R., and Schlicht, I. (1959). Estimation of small percentage of foetal haemoglobin. Nature, 184, 1877-1878.

Boyer, S. H., Margolet, L., Boyer, M. L., Huisman, T. H. J., Schroeder, W. A., Wood, W. G., Weatherall, D. J., Clegg, J. B., and Cartner, R. (1977). Inheritance of F cell frequency in heterocellular persistence of fetal hemoglobin: an example of allelic exclusion. American Journal of Human Genetics, 29, 256-271.

Carcassi, U. (1963). Aspetti medico sociali della microcitemia in Sardegna. In Atti Giornate Studio Microcitemia, Palermo, October 1963, pp. 34-48. Istituto Italiano di Medicina Sociale, Rome.

Galanello, R., Melis, M. A., Furbetta, M., Angius, A., Rosatelli, C., and Cao, A. (1978). Hemoglobin $H$ disease in Sardinia: phenotypic and genetic observations. Hemoglobin. (In the press.)

Galanello, R., Melis, M. A., Muroni, P. P., and Cao, A. (1977). Quantitation of $\mathrm{Hb} \mathrm{A}_{2}$ with DE-52 microchromatography in whole blood as screening test for $\beta$-thalassemia heterozygotes. Acta Haematologica, 57, 32-36.

Huisman, T. H. J., Schroeder, W. A., Brodie, A. N., Mayson, S. M., and Jakway, J. (1975). Microchromatography of hemoglobins. III. A simplified procedure for the determination of hemoglobin $\mathrm{A}_{2}$. Journal of Laboratory and Clinical Medicine, 86, 700-702.

Kan, Y. W., and Nathan, D. G. (1970). Mild thalassemia: the result of interactions of $a$ and $\beta$ thalassemia genes. Journal of Clinical Investigation, 49, 635-642.

Knox-Macaulay, H. H. M., Weatherall, D. J., Clegg, J. B., and Pembrey, M. E. (1973). Thalassaemia in the British. British Medical Journal, 3, 150-155.

Lauber, K. (1965). Determination of serum iron and iron binding capacity without deproteinization. Zeitung Kliniche Chemiche, 3 , 96-99.
Macciotta, A., Tentori, L., Zorcolo, G., Spano, B., and Spano, S. (1969). Considerazioni sugli aspetti clinici ed ematologici di 11 casi di emoglobinopatia J Sardegna. Annali Italiani di Pediatria, 22, 79-85.

Marti, H. R. (1963). Normale und Anomale Menschliche Hämoglobine. Springer, Berlin.

Mazza, U., Saglio, G., Caligaris Cappio, F., Camaschella, C., Neretto, G., and Gallo, E. (1976). Clinical and haematological data in 254 cases of $\beta$-thalassaemia trait in Italy. British Journal of Haematology, 33, 91-99.

Pearson, H. A., McPhedran, P., O'Brien, R. T., Aspnes, G. T., McIntosh, S., and Guiliotis, D. K. (1974). Comprehensive testing for thalassemia trait. Annals of the New York Academy of Sciences, 232, 135-144.

Pootrakul, P., Wasi, P., and Na-Nakorn, S. (1973). Haematological data in 312 cases of beta-thalassaemia trait in Thailand. British Journal of Haematology, 24, 703-711.

Silvestroni, E., and Bianco, I. (1945). Il metodo di Simmel per lo studio delle resistenze globulari. Policlinico (Prat), 51, 153-155.

Silvestroni, E., and Bianco, I. (1960). Dati statistici sulla frequenza della microcitemia e del morbo di Cooley nella Sardegna meridionale. Nuovi Annali di Igiene e Microbiologia, 11, 339348.

Siniscalco, M., Bernini, L., Filippi, G., Latte, B., Meera Khan, P., Piomelli, S., and Rattazzi, M. (1966). Population genetics of haemoglobin variants, thalassaemia and glucose-6-phosphate dehydrogenase deficiency, with particular reference to the malaria hypothesis. Bulletin of the World Health Organization, 34, 379393.

Tangheroni, W., Zorcolo, G., Gallo, E., and Lehmann, H. (1968). Haemoglobin J Sardegna: 50 (CD8) histidine $\rightarrow$ aspartic acid. Nature (London), 218, 470-471.

Tangheroni, W., Zorcolo, G., Gallo, E., and Lehmann, H. (1969). A new haemoglobin: Hb J Sardegna (alpha 50 histidine $\rightarrow$ aspartic acid). Helvetica Paediatrica Acta, 24, 174-182.

Terrenato, L. (1973). Beta and non-beta-thalassemia in Sardinia and their frequencies. Annals of Human Genetics, 36, 285-295.

Weatherall, D. J., Cartner, R., Clegg, J. B., Wood, W. G., Macrae, I. A., and MacKenzie, A. (1975). A form of hereditary persistence of fetal haemoglobin characterized by uneven cellular distribution of haemoglobin $\mathrm{F}$ and the production of haemoglobins $\mathrm{A}$ and $\mathrm{A}_{2}$ in homozygotes. British Journal of Haematology, 29, 205-220.

Wood, W. G., Weatherall, D. J., Clegg, J. B., Hamblin, T. J., Edwards, J. H., and Barlow, A. M. (1977). Heterocellular hereditary persistence of fetal haemoglobin (heterocellular HPFH) and its interaction with $\beta$ thalassaemia. British Journal of Haematology, 36, 461-473.

Requests for reprints to Professor A. Cao, Istituto 2 Clinica Pediatrica, Universita di Cagliari, Via Porcell 1 , Sardinia, Italy. 